\title{
Retórica do Arquivamento: patrimonialização, memória e esquecimento nos processos de tombamento do Centro Histórico Expandido de Campinas
}

\section{Lucas H. Gregate de Araujo*; Prof ${ }^{\mathrm{a}}$ Dr$^{\mathrm{a}}$ Cristina Meneguello (Orientadora).}

\section{Resumo}

Ao fim do século XIX e começo do século XX, Campinas passava por profundas mudanças: um dos principais centros do comércio cafeeiro oitocentista via um incipiente esforço modernizador se instaurar conforme a industrialização se concretiza. Com isso, a cidade presencia uma substancial mudança de seu centro, com novas construções aos moldes do estilo arquitetônico eclético se popularizando. Tais transformações marcam tanto a organização espacial, quanto a história de Campinas. Nesse contexto, o Conselho de Defesa do Patrimônio Cultural de Campinas (CONDEPACC), o departamento de história da Unicamp e a FAPESP dão início à produção do Inventário do Centro Histórico Expandido de Campinas, com o objetivo de catalogar esses imóveis e servir-lhes como ferramenta de preservação. No entanto, a grande maioria dos processos de tombamento abertos através do inventário são desfigurados e arquivados. A presente pesquisa, através deste estudo de caso, compreende os debates sobre o arquivamento como prática patrimonial e 0 sistema memória-esquecimento na produção historiográfica e no campo de discussões sobre o patrimônio histórico.

\section{Palavras-chave:}

Patrimônio Histórico, Tombamento, memória e esquecimento, História de Campinas.

\section{Introdução}

Campinas presenciou, entre o século XIX e o XX uma intensa dinamização de sua economia econômicas. A chegada da primeira ferrovia na cidade, em 1872, começa a transformar as lógicas produtivas da Princesa d'Oeste paulista. Consequentemente, ocorrem séries de mudanças estruturais e arquitetônicas presentes nos imóveis do no centro da cidade.

Anos depois, o CONDEPACC, fundado em 1987, inicia a produção de um inventário cujo recorte temático debruça-se justamente em tais imóveis. Depois de publicado, o inventário dá origem a inúmeros processos de estudo de tombamento de conjuntos desses imóveis. Porém, uma quantia ínfima recebe a chancela de patrimônio e o restante é arquivado ou fragmentado em processos individuais. O objetivo da presente pesquisa é fazer um estudo de caso dos processos gerados a partir do inventário e utilizá-lo para analisar o discurso patrimonial do arquivamento e seus impactos nas práticas do tombamento em Campinas e no Brasil.

\section{Resultados e Discussão}

Como passo teórico inicial, realizou-se um amplo levantamento bibliográfico, além da análise do próprio artigo publicado sobre o inventário, de autoria da arquiteta e urbanista Rita de Cássia Francisco, uma das técnicas e especialistas envolvidas em sua realização. Inferiu-se assim que, em sua concepção, a história patrimonial brasileira fora sempre calcada na fetichização do termo antigo e pauta-se na perda para estabelecer suas próprias políticas (GONÇALVES, p. 25, 1996).

Na sequência, fez-se um estudo documental. Da observação dos dados presentes nas atas de reunião do CONDEPACC - que apresentavam números conflitantes entre si - concluiu-se que dos 711 imóveis visitados e pré-inventariados, dentre 6868 fichados, apenas 57 foram tombados. Decidiu-se por selecionar quatro processos específicos para se realizar visitas técnicas e análises pormenorizada: I) Processo no. 12/08, II) Processo no. 18/08, III) Processo no. 24/08, IV) Processo no. 29/08. Por fim, com entrevistas recolhidas dos agentes envolvidos na realização do inventário, dos processos de tombamento e dos respectivos arquivamentos, encerrou-se a investigação das fontes primárias.

Figura 1. Alguns imóveis presentes no inventário.

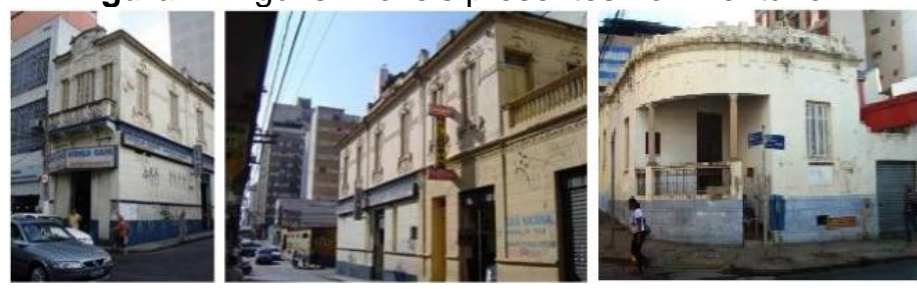

\section{Conclusões}

Através dos dados levantados, concluiu-se que houve grande descaracterização dos processos referidos e de parte da própria proposta que levou à produção do inventário. Com a divisão dos conjuntos e do arquivamento do estudo de tombamento da maioria dos imóveis, viu-se duplicar o ideal da perda na alegada retórica patrimonial: através da própria ação detratora do tempo em imóveis não preservados e no esquecimento outorgado por ação direta do arquivamento.

Por fim, surge, como produto teórico deste trabalho, o termo não-patrimônio, que se mostra uma sugestão profícua para categorizar os bens que entram em estudo de tombamento, porém são arquivados e todos os debates acerca do tema.

\section{Agradecimentos}

Agradeço ao $\mathrm{PIBIC} / \mathrm{CNPq}$ pelo fomento à pesquisa, à disponibilidade e gentileza de minha orientadora e ao esforço de todos que contribuíram atenciosamente.

CAMPINAS. Secretaria Municipal de Cultura. CONDEPACC. ATA 449 Campinas, SP, 2015. 16 p.

FRANCISCO, R. C. Inventário como ferramenta de preservação: a experiência da cidade de Campinas/SP. Revista CPC, São Paulo. n. 6. pp. 125, 2008.

GONÇALVES, José Reginaldo Santos. A retórica da perda: os discursos do patrimônio cultural no Brasil. Rio de Janeiro: Editora UFRJ/Ministério da Cultura/Sphan, 1996. 